\title{
Legal Protection Against the Trademark Property Rights "Bensu" (Ma Decision Analysis. No.:575 K/Ppdt.Sus-HKI / 2020)
}

\author{
Lalu Hulaifi Umami Kurniawan Muhammad Sood \\ Notary Master Study Program, Faculty of Law, University, Indonesia
}

\begin{abstract}
This research intends to examine how the form of legal protection of bensu trademark property in the perspective of the Trademark Law and whether the basis of legal considerations used by judges in dropping the verdict of the case number: $575 \mathrm{~K}$ / Pdt.Sus-HKI / 2020). The research method in this writing is normative legal research using primary, secondary, and tertiary legal materials. The analysis used is qualitative analysis. The results showed that the form of legal protection of bensu trademark property based on the perspective of the Brand Law is preventive legal protection that is legal protection before there is a violation of the law against the brand by registering the brand especially in order to get legal protection from the state, and repressive legal protection that is legal protection in case of violation of the law against the brand by filing a lawsuit of trademark cancellation, trademark infringement lawsuit, and temporary determination of the court to the Commercial Court. In addition, it can be done through alternative dispute resolution or through criminal charges. The basic legal considerations used by the judge in dropping the verdict of the case number: $575 \mathrm{~K} / \mathrm{Pdt}$.Sus- HKI/2020, is based on a constitutional system first to file. The judge only considers this case as a case concerning the first registrant of brands and brands that have similarities in essence or in whole. The judge did not notice that the word BENSU is the name or abbreviation of the name of a famous person that belongs to Ruben Samuel Onsu.
\end{abstract}

Keywords: brand, legal protection

DOI: $10.7176 / \mathrm{JLPG} / 106-05$

Publication date: February $28^{\text {th }} 2021$

\section{Introduction}

Intellectual Property Rights are the result of human intellectuals incarnated in a form of creation or invention. (Muhammad, 2012) One part of intellectual property rights is a mark which is a sign in the form of images, names, words, letters, numbers, color arrangements, or a combination. of these elements which have distinctive power and are used in trading activities of goods or services which are the basis for the development of modern trade which can be used as Goodwill, a symbol, quality standards, a means of penetrating all types of markets, and traded with guarantees to generate large profits.

If a brand is widely known, this can lead to legal problems, such as the emergence of competitors with bad faith to impersonate or even pirate a well-known brand. With this imitation, producers are disadvantaged because their production turnover is directly reduced.

In order to obtain legal protection for a mark, the trademark owner must first register the mark. This is in accordance with the existing provisions in Law Number 20 of 2016 concerning Marks and Geographical Indications, which explains the granting of rights to trademarks, namely in Article 1 paragraph (5), which states that "rights to marks are exclusive rights. given by the state to the owner of a registered mark for a certain period by using the mark himself or giving permission to other parties to use it. "Article 3, states that "the right to a mark is obtained after the mark is registered." Then in Article 35, it also states that "registered marks receive legal protection for a period of 10 (ten) years from the date of receipt." 2 .

One of the cases of trademark disputes in Indonesia which is the compiler is careful, namely the trademark dispute "BENSU", between Ruben Samuel Onsu and PT. Chicken Geprek Benny Sujono. Where, Ruben Samuel Onsu, claims to be the owner of the rights and the first registrar of a trademark containing the word BENSU and states that the word BENSU is an abbreviation of the name Ruben Samuel Onsu. Then to take advantage of the usefulness of the word BENSU, Ruben Samuel Onsu used the word BENSU in his culinary business, namely Geprek Bensu.

Ruben Samuel Onsu objected because there were other companies using the word BENSU, namely PT. Ayam Geprek Benny Sujono with his culinary business I Am Geprek Bensu. For this incident, Ruben Samuel Onsu sued PT. Ayam Geprek Benny Sujono on the use of the name BENSU to the Central Jakarta Commercial Court, on August 23, 2019. In response to this, PT. Ayam Geprek Benny Sujono, stated that his party was the first registrar and legal owner of the BENSU trademark. The word BENSU itself stands for Benny Sujono. Then the party from PT. Ayam Geprek Benny Sujono, filed a counterclaim (rekonpensi). As for the decision of the Central Jakarta Commercial Court, on January 13, 2020, namely rejecting Ruben Samuel Onsu's lawsuit completely and granting the counterclaim (rekonpensi) of PT. Chicken Geprek Benny Sujono for some. The 
verdict also stated that PT. Ayam Geprek Benny Sujono is the owner and first authorized user of the BENSU brand. Meanwhile, the 6 BENSU brands registered by Ruben Samuel Onsu were declared null and void with all the legal consequences.

Furthermore, Ruben Samuel Onsu submitted an appeal to the Supreme Court, on April 23, 2020, with case number: 575 K / Pdt.Sus-HKI / 2020. However, the Supreme Court, rejected Ruben Samuel Onsu's appeal and strengthened the decision of the Central Jakarta Commercial Court.

That the dispute over the BENSU trademark between Ruben Samuel Onsu and PT. Chicken Geprek Benny Sujono is interesting to do further research, because in this case both Ruben Samuel Onsu and PT. Ayam Geprek Bensu, both of them have trademarks that are registered in the General Register at the Directorate General of IPR. Based on the description, the writer wishes to conduct research on the thesis entitled "LEGAL PROTECTION AGAINST TRADEMARK PROPERTY RIGHTS" BENSU "(Analysis of the Supreme Court Decision Number: 575 K / Pdt.Sus / -HKI / 2020).

\section{Research methods}

This research is a normative legal research. The types of approach to the problem that the author uses include:(Marzuki, 2017) (1) a statute approach; (2) conceptual approach (conceptual approach); (3) the case approach (case appoarch). The main object of study in the case approach is the ratio decidendi or reasoning, namely the court's consideration to arrive at a decision.

Types and sources of legal materials used in this research include (1) primary legal materials, namely binding legal materials such as Law no. 20 of 2016 concerning Trademarks and Geographical Indications, Civil Code, Decision of the Supreme Court of the Republic of Indonesia Number: 575 K / Pdt.Sus-HKI / 2020, and Decision of the Central Jakarta Commercial Court Number: 57 / Pdt.Sus-Mark / 2019 / PN Niaga.Jkt.Pst.(Salim \& Nurbani, 2013); (2) Secondary legal materials such as books, dictionaries, papers, journals, and research results related to the legal issues under study;(Azikin, 2004) (3) Tertiary Legal Materials Tertiary legal materials such as legal dictionaries, language dictionaries, encyclopedias and legal encyclopedias.(Salim \& Nurbani, 2013)

The technique of collecting legal materials that researchers use is to use documentary studies. Another approach to analysis used in this study is qualitative analysis. The method of concluding legal materials is done deductively (from general to specific).

\section{Results and discussion}

\subsection{Case for Bensu Trademarks}

Of course, a dispute that is submitted to court consists of the Plaintiffs against the Defendants. In order to obtain a balanced picture in the context of seeking and and finding justice, the court (judge) is required to hear the arguments put forward by the Defendant. This is a principle contained in procedural law in court, namely the principle of hearing both parties or known as the principle of audi et alteram partem (Sunarto, 2014). Related to the BENSU trademark dispute, which started with a lawsuit filed by Ruben Samuel Onsu with a lawsuit letter dated August 22, 2019 which was received and registered at the Registrar's Office of the Commercial Court at the District Court on August 22, 2019 in Register Number 57 / Pdt.Sus-HKI / Brand / 2019 / PN Niaga Jkt.Pst. In this case Ruben Samuel sued PT. Ayam Geprek Benny Sujono as the first defendant and the Ministry of Law and Human Rights, $\mathrm{Cq}$ the Directorate General of Intellectual Property Rights as defendant II (in causa codefendant).

Ruben Samuel Onsu, claims that he is the owner of the rights and the first registrar (First to File) of the BENSU mark. According to Ruben Samuel Onsu, his BENSU trademark has been requested for registration since September 3, 2015 and registered on June 7, 2018, and has received protection until September 3, 2025. Ruben Samuel Onsu also stated that he is the owner of the rights to the mark containing the words " Other BENSU" registered in the General Register of Marks at the Directorate General of Intellectual Property Rights. In addition, Ruben Samuel Onsu stated that the word BENSU is synonymous with the abbreviation of the plaintiff's name (ruBEN onSU) which has been recognized by the wider community as an Indonesian artist, even the plaintiff has obtained legality over the use of the name BENSU as an abbreviation of the name Ruben Onsu which is attached and becomes one - an integral part of the plaintiff's name, as stipulated in the South Jakarta District Court No. 384 / Pdt.P / 2018 / PN.Jkt.Sel., Dated 30 May 2018.

Furthermore, Ruben Samuel Onsu objected to the use of the word BENSU used by PT. Ayam Geprek Benny Sujono, in his culinary business, namely I AM Geprek Bensu Sedep Beneerrr, without his permission. Ruben Samuel Onsu also objected to the registration of a trademark using the word BENSU, namely I AM Geprek Bensu or it can be called Ayam Geprek Bensu. Responding to Ruben Samuel Onsu's lawsuit, PT. Geprek Benny Sujono, as the defendant, stated that he rejected and denied the lawsuit. The Defendant also stated that it was not true that the Plaintiff was the owner of the rights and first registrar (First to File) of the BENSU brand, because the owner of the BENSU trademark itself was originally registered in the name of the owner Jessy Reliim, in which the BENSU mark by Jessy Reliim was used as the SUSU mark and the brand BENSU is taken 
from the abbreviation of the name Bengkel Susu. Because previously, Ruben Samuel Onsu had filed a civil suit regarding the "BENSU" brand against another businessman, namely Jessy Reliim. The lawsuit was submitted to the Commercial Court at the Central Jakarta District Court, with register number 48 / Pdt-Sus / Merek / 2018 / PN Niaga. Jkt. Pst., On 25 September 2018. However, to avoid protracted cases because later it will consume a lot of time, thought, energy, and money. Finally, Ruben Samuel Onsu and Jessy Reliim decided to make peace, which was based on a sale and purchase agreement and the transfer of rights to the brand (Trademark Certificate) In the peace agreement, Ruben Samuel Onsu agreed to buy the BENSU and Jessy Reliimim brands.

According to PT. Ayam Geprek Benny Sujono, the transfer of rights to the BENSU brand from Jessy Reliimim to Ruben Samuel Onsu had no legal consequences for the culinary business I AM Geprek Bensu, on the grounds that the transfer of rights to the "BENSU" brand occurred after PT. Ayam Geprek Benny Sujono submitted an application for registration on May 3, 2017 to the Directorate General of IPR. I Am Geprek Bensu, which has been operating since 17 April 2017 until now and has been filed for the trademark application on 03 May 2017. I Am Geprek Bensu was founded by Yangcent, Kurniawan, and Stefani Livinus. Then so that the food business can take the form of a legal entity, then based on the Limited Liability Company Deed, PT. Ayam Geprek Benny Sujono Number 130 dated 15 March 2017 made by Netty Maria Machdar, S.H., Notary in Jakarta, by Yangcent, Kurniawan and Stevani Livinus. PT. Ayam Geprek Benny Sujono is abbreviated as Ayam Geprek Bensu, whose Articles of Association have been approved based on the Decree of the Minister of Law and Human Rights of the Republic of Indonesia Number AHU-0040249.AH.01.01.Tahun 2017 dated 13 September 2017.

That is by using the name Benny Sujono who is also called BENSU as the name of the legal entity PT. Ayam Geprek Benny Sujono, abbreviated as Ayam Geprek Bensu, is a tribute to Benny Sujono, who is also known as BENSU, who has provided many suggestions and input to the establishment of a Legal Entity and the opening of the first I AM Geprek Bensu food business on April 17 2017, which having its address at Jalan Padamengan I Gang 5 number 2A, Gunung Sahari, East Pademangan District, North Jakarta. Furthermore, Ruben Samuel Onsu's younger brother, Evan Jordi Onsu, offered to participate in the food business as Operations Manager. Because Evan Jordi Onsu is Yangcent and Stefani Livinus' playmate, Evan Jordi Onsu's offer was accepted. So that there was cooperation in the management of the I Am Geprek Bensu brand food business, but this collaboration was only limited to managing the food business and not having the I Am Geprek Bensu brand food business.

After the I Am Geprek Bensu food business began to develop with the opening of several new branches / outlets. Then Evan Jordi Onsu, offered his brother Ruben Samuel Onsu, who is an artist who is widely known and has many fans, to be used as a promotional ambassador (ambassador) of the I Am Geprek Bensu brand food business. Finally, PT Ayam Geprek Benny Sujono agreed to make Ruben Samuel Onsu an ambassador by posting a photo of Ruben Samuel Onsu in a number of branches / outlets of the food business brand I Am Geprek Bensu and Ruben Samuel Onsu did not care about the word and / or name BENSU. in the food business brand I Am Geprek Bensu. In connection with his position as a promotional ambassador (ambassador) and as compensation Ruben Samuel Onsu has received the payment of cash for profit sharing (Golden Share).

After joining the I Am Geprek Bensu business, Ruben Samuel Onsu through his younger brother, Evan Jordi Onsu, asked that one employee be employed in the kitchen or as quality control of the I Am Geprek Bensu brand food business. The Plaintiff withdrew his employee and in August 2017 the Plaintiff opened a Geprek Bensu brand food business, which has the same type of food, wording, name, color arrangement, image and logo with PT. Chicken Geprek Benny Sujono. Since opening the Geprek Bensu brand food business, Ruben Samuel Onsu began promoting the Geprek Bensu Chicken food business, causing confusion among the public and consumers of I Am Geprek Bensu PT. Many Geprek Chicken Benny Sujono have switched to Geprek Bensu Ruben Samuel Onsu. Furthermore, PT. Ayam Geprek Benny Sujono, put forward a counterclaim (rekonpensi) against Ruben Samuel Onsu

Regarding the dispute over the BENSU trademark dispute, the Commercial Court at the Central Jakarta District Court, finally decided to reject Ruben Samuel Onsu's lawsuit completely and granted the counter suit (rekonpensi) of PT. Chicken Geprek Benny Sujono. The verdict also stated that PT. Ayam Geprek Benny Sujono, as the owner and first legal user of the I AM Geprek Bensu brand. Then the 6 BENSU brands that were registered by Ruben Samuel Onsu, were declared null and void with all the legal consequences.

Ruben Samuel Onsu was not satisfied with the Commercial Court Decision No. 57 / Pdt.Sus-Mark / 2019 / PN.Niaga.Jkt.Pst. Finally, Ruben Samuel Onsu filed an appeal to the Supreme Court of the Republic of Indonesia with the intention of explaining and expressing his objections and dissatisfaction with the previous District Court Decision. Furthermore, in the appeal of the Cassation Decision Number 575 / Pdt.Sus-HKI / 2020. The Supreme Court, stated the following:

"Considering, that with regard to the cassation memorandum, Cassation Respondent I has submitted a counter-memorandum of cassation dated February 21, 2020, which basically asked the Supreme Court to reject the cassation petition from the Cassation Petitioner; 
Considering, whereas against these reasons the Supreme Court is of the opinion:

That the reasons for the cassation cannot be justified, because after carefully examining the cassation memorandum dated 3 February 2020 and the counter memory dated 21 February 2020 linked to Judex Facti's consideration, in this case the Commercial Court at the Central Jakarta District Court, the Supreme Court is of the opinion that Judex Facti is not wrong apply the law with the following considerations:

Whereas the mark belonging to the Plaintiff of the Convention, namely "BENSU + Lukisan" in class 43 stands for Bengkel Susu with the description in black, red, gray and white with the dominant image of a cow and a wrench (vide evidence P-1, P-2A and P-2B), apparently they have no similarities in terms of both the form of writing and the sound of speech with the mark belonging to Defendant I of the Convention, namely I AM GEPREK BENSU SEDEP BENEERRR + description painting in yellow, green, red, black and white, dominated by a picture of a chicken in flames, registration IDM000643531 class 43 (vide evidence TI - 3), so that the Plaintiff's argument regarding the similarity between the Marks of the Plaintiffs of the Convention and the marks of Defendant I of the Convention is not proven;

Whereas the Plaintiff for the Reconvention (Defendant I of the Convention) can prove that he is the owner of the I AM GEPREK BENSU SEDEP BENEERRR mark + painting IDM Registration Number 000643531 registration date May 3, 2017, at grade 43;

Whereas from 9 May 2017 to 14 August 2017, the Reconvention Plaintiff (Defendant I of the Convention) has provided compensation to the Reconvention Defendant (Plaintiff of the Convention) in connection with his position as Promotional Ambassador in 10 (ten) branches (outlets) of the food business brand "I AM GEPREK BENSU "belonging to the Reconvention Plaintiff (vide evidence of T.I - $24 \mathrm{~s} / \mathrm{d}$ T.I - 33) so that the Reconvention Defendant must realize that his position is only as an Ambassador / Promoter of the Mark of the Reconvention Plaintiff; Whereas thus the efforts of the Reconvention Defendant were based on bad faith because they took the consumer market from the Reconvention Plaintiff; Considering, whereas based on the aforementioned considerations, it turns out that the decision of the Commercial Court at the Central Jakarta District Court in this case does not contradict the law and / or law, so that the cassation petition filed by the Cassation Petitioner: RUBEN SAMUEL ONSU must be rejected; Considering, that because the appeal of the Cassation Petitioner was rejected, the Cassation Applicant must be punished to pay the case fees at this cassation level; Noting, Law Number 20 of 2016 concerning Marks and Geographical Indications, Law Number 48 of 2009 concerning Judicial Powers, Law Number 14 of 1985 concerning the Supreme Court as amended by Law Number 5 of 2004 and amendments secondly, by Law Number 3 of 2009, as well as other relevant laws and regulations;

\section{JUDGING:}

1. Reject the cassation petition from the Cassation Applicant: the said RUBEN SAMUEL ONSU;

2. Punish the Cassation Petitioner to pay court fees in the cassation rate of Rp. 5,000,000.00 (five million rupiah).

Thus, based on the Supreme Court Decision, the appeal filed by Ruben Samuel Onsu did not bear fruit because the Supreme Court refused and instead reinforced Decision Number 57 / Pdt.Sus-Mark / 2019 / PN.Niaga.Jkt.Pst

\subsection{Analysis of Legal Considerations Used by Judges in Decision on Case Number 575 / Pdt.Sus-HKI / 2020}

Judge's consideration is one of the most important aspects in determining the realization of the value of a Judge's Decision which contains justice (ex aequo et bono), contains legal certainty and legal usefulness. The judge's decision must consider all aspects of a juridical, philosophical and sociological nature, so that the justice that is wanted to be achieved, realized and accounted for in the judge's decision is justice oriented towards legal justice (legal justice), moral justice (moral justice), and community justice ( social justice). Judges in making decisions must pay attention to and consider all aspects in it, starting from the need for caution, as little as possible avoiding imprecision, both formal and material to the technical skills of making them.(Rifai, 2010)

In carrying out the main duties of a judge, in Article 5 Paragraph (1) of Law Number 48 of 2009 concerning judicial power it is stated that this provision is intended so that the decisions of judges and constitutional judges are in accordance with the law and the sense of justice of the community. According to Van Apeldorn, a Judge in his duties must pay attention and firmly base on the principle of adjusting the Law with concrete facts and in the classic view of the Conservative school which was southeast by Montesquieu and also Immanuel Kant argued that the Judge in stipulating laws against legal events actually does not carry out its role independently. Judges are only mouthpieces or mouthpieces of the Law, so they cannot change the legal force of the Law.

Analysis on the basis of legal considerations used by the judge in ruling on case number $575 \mathrm{~K} / \mathrm{Pdt}$.SusHKI / 2020, namely the BENSU trademark dispute between Ruben Samuel Onsu and PT. Chicken Geprek Bensu. The judge saw the BENSU case as a case concerning the party who first registered the constitutive mark (first to file) and the mark which had similarities in essence or in its entirety. The judge did not see this case as a case of using the name or abbreviation of a famous person, namely the word BENSU as an abbreviation for Ruben Samuel Onsu's name, which was registered earlier by another party. That the Supreme Court judge is the 
highest court and the last remedy, it should pay attention to the provisions of Article 20 Algemen Bepalingen van Wetgeving voor Indonesie (AB), which states that judges must judge based on law. In addition, in the principle of decision based on Article 178 paragraph (2) HIR / Article 189 paragraph (2) of the RBG and Article 50 RV, namely "the decision must be totally and thoroughly examined and adjudicating every aspect of the lawsuit submitted. It is not permissible to only examine and decide part of it and ignore the rest of the lawsuit. this way of judging is not in accordance with the principles outlined by law. "

In addition, the judge's decision must be based on clear, detailed and consideration enough. This is confirmed in Article 50 of Law Number 48 Year 2009 concerning Judicial Powers, which states that "Court decisions must not only contain the reasons and basis for the decision, but also contain certain articles of the relevant laws and regulations or an unwritten source of law on which to base the decision. to judge. " Based on these provisions, the Supreme Court judge should be the highest court and as a final legal effort to see and pay attention to the contents of Ruben Samuel Onsu's lawsuit which states that the word BENSU is an abbreviation of the name of a famous person, namely Ruben Samuel Onsu. Ruben Samuel Onsu is an Indonesian artist who has been active in the television entertainment industry and his name has been widely known by the public since 2006. The word BENSU itself is an abbreviation of the name and has become an inherent icon and has become a unity with Ruben Samuel Onsu, as stipulated. South Jakarta District Court Number: 384 / Pdt.P / 2018 / PN.Jkt.Sel.

The South Jakarta District Court, has given Determination Number: 384 / Pdt.P / 2018 / PN.Jkt, .Sel.

Furthermore, the judge determined Ruben Samuel Onsu's petition, as follows:

1. Granted Ruben Samuel Onsu's Request

2. Determining the name "BENSU" is an abbreviation of the name "Ruben Onsu"

3. Declare legal and have legal force. Determination of the name BENSU as an abbreviation of the name Ruben Onsu

In addition, based on the provisions concerning trademark registration, it has been regulated in Article 21 paragraph (2) letter a of Law Number 20 of 2016 concerning Marks and Geographical Indications, which states that "Application is rejected if the mark is or resembles a person's name or abbreviation. well-known, photograph, or name of a legal entity owned by another person, except with the written consent of the party entitled. " As for Article 76 of Law Number 20 of 2016 concerning Marks and Geographical Indications, it states that "a lawsuit for cancellation of a registered mark can be filed by interested parties based on the reasons as referred to in Article 20 and / or Article 21."

The author is of the opinion that the basis for legal considerations used by the judge in making a decision in this BENSU trademark dispute is based on a constitutive system (first to file). The judge only sees this case as a case concerning the first registrant of a mark and a mark which has similarities in essence or in its entirety. In his decision the judge stated that PT. Ayam Geprek Benny Sujono with his culinary business, namely I AM Geprek Bensu, as the registrant owner and first legal user of the brand I AM Geprek Bensu Sedep Beneerrrr, abbreviated as Ayam Geprek Bensu. Meanwhile, the I AM Geprek Bensu brand owned by Ruben Samuel Onsu, has the same substantially or entirely with the brand owned by PT. Chicken Geprek Benny Sujono.

The brand owned by PT. Ayam Geprek Benny Sujono as the owner and first registrar of the canceled I AM GEPREK BENSU SEDEP BENEERRR brand and Ruben Samuel Onsu's trademark, are as follows:

Table 1. Trademarks of PT. Chicken Geprek Benny Sujono

\begin{tabular}{|c|c|c|c|c|c|c|}
\hline Merek & No. Pendaftaran & $\begin{array}{l}\text { Kode } \\
\text { Kelas } \\
\end{array}$ & $\begin{array}{l}\text { Tanggal } \\
\text { Penerimaan }\end{array}$ & $\begin{array}{l}\text { Tanggal } \\
\text { Pendaftaran }\end{array}$ & Etiket & Pemilik \\
\hline $\begin{array}{l}\text { I } \quad \text { AM } \\
\text { GEPREK } \\
\text { BENSU SEDEP } \\
\text { BENEERR R + } \\
\text { LUKISAN }\end{array}$ & IDM00064353 1 & 43 & 03 Mei 2017 & 24 Mei 2019 & & $\begin{array}{l}\text { PT. AYAM } \\
\text { GEPRE K } \\
\text { BENNY } \\
\text { SUJON O }\end{array}$ \\
\hline
\end{tabular}

Table 2. Trademark Ruben Samuel Onsu

\begin{tabular}{|c|c|c|c|c|c|c|}
\hline Merek & No. Pendaftaran & $\begin{array}{l}\text { Kode } \\
\text { Kelas }\end{array}$ & $\begin{array}{l}\text { Tanggal } \\
\text { Penerimaan }\end{array}$ & $\begin{array}{l}\text { Tanggal } \\
\text { Pendaftaran }\end{array}$ & Etiket & Pemilik \\
\hline $\begin{array}{l}\text { I AM } \\
\text { GEPREK BENSU } \\
\text { SEDEP } \\
\text { BENEERRR } \\
+ \text { LUKISAN }\end{array}$ & IDM000643596 & 45 & $\begin{array}{l}08 \text { Agustus } \\
2017\end{array}$ & 24 Mei 2019 & & $\begin{array}{l}\text { Ruben } \\
\text { Samuel Onsu }\end{array}$ \\
\hline
\end{tabular}


In addition to the cancellation of the Ruben Samuel Onsu mark above, the judge also declared it null and void with all the legal consequences of registering a trademark in the name of Ruben Samuel Onsu and the judge ordered the Directorate General of Intellectual Property Rights to cancel the marks in the name of Ruben Samuel Onsu by crossing out the brands. from the Indonesian Register of Marks, with all the legal consequences, the 6 (six) marks which were also canceled are as follows:

Table 3. List of brand cancellations

\begin{tabular}{|c|c|c|c|c|c|c|}
\hline No & Merek & No. Pendaftaran & $\begin{array}{l}\text { Kode } \\
\text { Kelas }\end{array}$ & $\begin{array}{l}\text { Tanggal } \\
\text { Penerimaan }\end{array}$ & $\begin{array}{l}\text { Tanggal } \\
\text { Pendaftaran }\end{array}$ & Pemilik \\
\hline 1 & $\begin{array}{l}\text { GEPREK BENSU + } \\
\text { LUKISAN }\end{array}$ & IDM000643591 & 43 & $\begin{array}{l}\text { 08 Agustus } \\
2017\end{array}$ & $\begin{array}{l}24 \mathrm{Mei} \\
2019\end{array}$ & $\begin{array}{l}\text { Ruben Samuel } \\
\text { Onsu }\end{array}$ \\
\hline 2 & \begin{tabular}{|l|} 
I AM GEPREK \\
BENSU + LOGO
\end{tabular} & IDM000643590 & 43 & $\begin{array}{l}24 \text { Agustus } \\
2017\end{array}$ & 24 Mei 2019 & $\begin{array}{l}\text { Ruben Samuel } \\
\text { Onsu }\end{array}$ \\
\hline 3 & $\begin{array}{l}\text { GEPREK BENSU } \\
+ \text { LOGO }\end{array}$ & IDM000643594 & 43 & $\begin{array}{l}24 \text { Agustus } \\
2017\end{array}$ & 24 Mei 2019 & $\begin{array}{l}\text { Ruben Samuel } \\
\text { Onsu }\end{array}$ \\
\hline 4 & $\begin{array}{l}\text { GEPREK BENSU } \\
+ \text { LOGO }\end{array}$ & IDM000643587 & 43 & $\begin{array}{l}31 \text { Agustus } \\
2017\end{array}$ & 24 Mei 2019 & $\begin{array}{l}\text { Ruben Samuel } \\
\text { Onsu }\end{array}$ \\
\hline 5 & BENSU & IDM000643595 & 43 & 03 April 2018 & 24 Mei 2019 & $\begin{array}{l}\text { Ruben Samuel } \\
\text { Onsu }\end{array}$ \\
\hline 6 & $\begin{array}{l}\text { GEPREK BENSU } \\
\text { REALby RUBEN } \\
\text { SAMUEL ONSU }\end{array}$ & IDM000643589 & 43 & 25 Juni 2018 & $\begin{array}{l}24 \mathrm{Mei} \\
2019\end{array}$ & $\begin{array}{l}\text { Ruben Samuel } \\
\text { Onsu }\end{array}$ \\
\hline
\end{tabular}

The cancellation of the 6 brands above is due to the similarity in principle or in whole with the I AM GEPREK BENSU SEDEP BENEERRR brand owned by PT .AYAM GEPREK BENNY SUJONO abbreviated as AYAM GEPREK BENSU, Registration Number IDM000643531, Class 43, Date of Acceptance May 032017, Registration Date May 242019 , the name of the owner of PT. AYAM GEPREK BENNY SUJONO and is or resembles the name or abbreviation of the name of the Legal Entity, namely PT. CHICKEN GEPREK BENNY SUJONO abbreviated as CHICKEN GEPREK BENSU. That the basis for legal considerations used by the judge in ruling the case number: $575 \mathrm{~K} /$ Pdt.Sus-HKI / 2020 The judge did not see and heed that the word BENSU itself first became an inherent icon and became an integral part of the person's name or abbreviation. famous namely Ruben Samuel Onsu. The word BENSU has been recognized by the public as an abbreviation of Ruben Samuel Onsu's name. However, Ruben Samuel Onsu was late in registering the name or abbreviation of his name to the Directorate General of IPR, because Ruben Samuel Onsu was previously unaware and did not expect that his name abbreviation would be used or utilized or registered earlier by another party as a trademark without his permission.

In connection with the occurrence of the BENSU trademark dispute in this study, the author states that the Government through the Directorate General of Intellectual Property Rights must optimize the socialization and counseling related to brand regulations in order to increase public knowledge and understanding of brands. Then the Directorate General of Intellectual Property Rights, must be more careful, careful and thorough and selective in examining trademark registration in order to minimize problems in the future. Furthermore, trademarks owners should register their marks immediately, before the marks are used and registered by other parties. Likewise, owners of well-known names and / or abbreviations who want to take advantage of and utilize their fame as a business or business opportunity so as to immediately register their name / abbreviation as a brand.

\section{Conclusion}

Based on the results of the research and discussion above, the authors draw the following conclusions:

1. The form of legal protection for BENSU trademark property rights based on the perspective of the Trademark Law is a form of preventive legal protection and a form of repressive legal protection. Preventive legal protection is legal protection before a trademark violation occurs by registering the mark first. Because the right to a mark is obtained after the mark is registered and the registered mark gets legal protection from the state. In this case, it depends on the awareness of the trademark owner to register his mark in order to get legal protection from the state. Repressive legal protection is a form of legal protection that is carried out if a legal violation against a trademark occurs which can be done by filing a trademark cancellation suit, a trademark infringement suit and a temporary court order to the Commercial Court. In addition, it can also be done through alternative dispute resolution (ADR) or through criminal prosecution.

2. Whereas the basis for legal considerations used by the judge in ruling on case number: $575 \mathrm{~K} / \mathrm{Pdt}$.Sus-HKI / 2020 , is based on a first to file constitutive system. The judge only sees and pays attention to this case as a case concerning the first registrant of marks and marks which have similarities in essence or in their entirety. That the basis for legal considerations used by the judge in ruling on case number: $575 \mathrm{~K} / \mathrm{Pdt}$.Sus-HKI / 2020. The judge did not see and noticed that the word BENSU was a name or an abbreviation of the name of 
a famous person, namely Ruben Samuel Onsu's. The judge should have noticed the word BENSU as an abbreviation of the name Reuben Samuel Onsu.

\section{References}

\section{Book}

Amiruddin, H. Zainal Asikin, (2012). Pengantar Metode Penelitian Hukum, Cetakan ke-6, Edisi Pertama, Penerbit: PT. Raja Grafindo Persada, Jakarta.

Asikin, Z. (2004). Amiruddin. Pengantar Metode Penelitian Hukum. Jakarta: Raja Grafindo Persada.

Marzuki, M. (2017). Penelitian Hukum: Edisi Revisi. Prenada Media.

Muhammad, A. (2001). Kajian hukum ekonomi hak kekayaan intelektual. Citra Aditya Bakti.

Rifai, A. (2010). Penemuan hukum oleh hakim: dalam perspektif hukum progresif. Sinar Grafika.

Salim, H. S., \& Nurbani, E. S. (2013). Penerapan Teori hukum pada penelitian tesis dan disertasi. Raja Grafindo Persada, Jakarta.

Sunarto. (2014). Peran aktif hakim dalam perkara perdata. Kencana.

\section{Legislation}

Indonesia, Undang-UndangNomor 20 Tahun 2016 tentangMerek dan IndikasiGeografis

Indonesia, Undang-UndangNomor 48 tentangKekuasaanKehakiman

Indonesia, Undang-UndangNomor15 Tahun 2001tentangMerek

Indonesia, Kitab Undang-Undang Hukum Perdata

Indonesia, Putusan Pengadilan Niaga Jakarta Pusat Nomor : 57/Pdt.Sus-Merek/2019/PN Niaga.Jkt.Pst

Indonesia, Putusan Mahkamah Agung Republik Indonesia Nomor : 575K/Pdt.Sus-HKI/2020

Internet

http://ditjenpp.kemenkumham.go.id/umum/849-penemuan-hukum-oleh-hakim. 